\title{
Performance and egg quality of aged laying hens fed diets supplemented with meat and bone meal or oyster shell meal
}

\author{
A.U. Çatlı ${ }^{1}$, M. Bozkurt ${ }^{1 \#}$, K. Küçükyılmaz ${ }^{1}$, M. Çınar ${ }^{1}$, E. Bintaş ${ }^{1}$, F. Çöven ${ }^{2}$ \& H. Atik ${ }^{2}$ \\ ${ }^{1}$ Erbeyli Poultry Research Institute - Aydın/Turkey \\ ${ }^{2}$ Bornova Veterinary Control and Research Institute - İzmir/Turkey
}

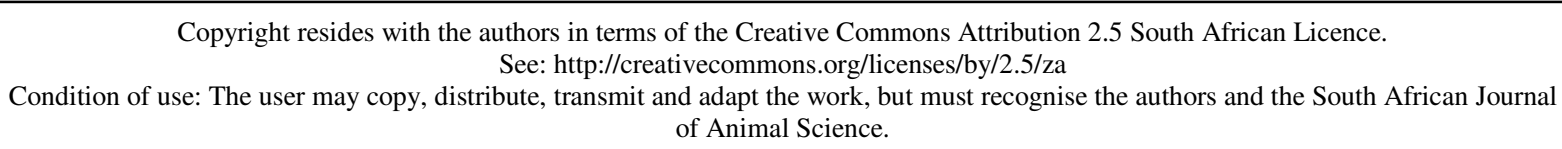

\begin{abstract}
Meat and bone meal (MBM) and oyster shell meal (OSM) were supplemented to a basal diet (LMS), either alone or in combination, in order to assess the dietary influences of those complementary Ca sources on performance and egg quality of laying hens. Four hundred and thirty-two Brown-Nick hens, at the beginning of their second production period, were divided into four treatment groups with six replicates each. The final body weight of OSM-fed hens was highest, whereas others did not differ significantly. Hens receiving OSM produced more eggs and egg mass along with considerably greater feed intake than those on all the other treatments. Egg weight was not affected by the treatments except for the lower egg weight of the MBM+OSM treatment. Hens fed a diet supplemented with MBM laid at a rate of 1.14\%, 3.66\% points lower than those on the control and OSM treatments, respectively. Feed efficiency was not influenced by origin of calcium source. Egg shape index and eggshell weight did not differ among treatments. Eggshell thickness and eggshell breaking strength were higher in hens fed with MBM as compared to control and OSM fed birds. Similar to the tendency in shell quality, MBM inclusion in the diet tended to enhance albumen height and Haugh unit. Dietary treatment with OSM resulted in the highest serum $\mathrm{Ca}$ and $\mathrm{P}$ concentrations. These results indicate that partially replacing limestone with OSM in the laying hen diet provided significant improvements in egg production performance, whereas most of the egg quality traits were enhanced by dietary supplementation with MBM at $4 \%$.
\end{abstract}

Keywords: Animal by-product, egg shell traits, performance, serum mineral concentration

${ }^{\#}$ Corresponding author: mehmetbozkurt9@ hotmail.com

\section{Introduction}

As a result of continuous and rapid selection for more egg production and heavier egg weight, current commercial layer hybrids produce more than 350 eggs and a total of $21 \mathrm{~kg}$ egg mass throughout the $60 \mathrm{wk}$ laying period. It is worth noting that daily feed intake and the body weight of commercial layers have been reduced through intensive selection programmes in spite of the increased egg mass production compared to previous years. This means, potentially, that less calcium $(\mathrm{Ca})$ is available for eggshell calcification (Rao \& Roland, 1989; Roberts, 2004) and some producers have been confronted with serious shell quality problems. Hence, poor eggshell quality has been a major economic concern to commercial egg producers with serious economic losses due to levels of downgraded eggs ranging from 6\% to 20\% (Roland, 1988; Keshevarz \& Nakajima, 1993; Hunton, 2005).

Since $97 \%$ of the eggshell consists of calcium carbonate, $\mathrm{Ca}$ is an essential element for eggshell formation and construction (Parsons \& Combs, 1981; Hunton, 1995). Limestone is the principal supplemental $\mathrm{Ca}$ source used in laying hen rations due to its abundant natural reserves, low cost, and easy incorporation into layer feeds. Different aspects of shell quality were reported to be improved by the partial replacement of limestone with oyster shells in the diet (Hunton, 1995; 2005; Roberts, 2004). 
The importance of the identification of the Ca bioavailability of different complementary Ca sources and also the ideal $\mathrm{Ca}$ particle size in laying hens has been of great interest to researchers for a long time (Guinotte \& Nys, 1991; De Witt et al., 2008). Experiments have been undertaken to determine if it is possible to further improve eggshell quality by substitution of oyster shell for part or all of the ground limestone in the complete laying ration. Several studies have discovered that providing $\mathrm{Ca}$ in the form of oyster shells results in higher digestibility and retention than the same amount of calcium carbonate fed as ground limestone (Scott et al., 1971; Mongin \& Sauveur, 1974; Roland, 1988). It was hypothesized that the reason for this was that the larger particles of oyster shells took longer to digest because they remained in the gizzard and were slowly dissolved over a prolonged period (Scott et al., 1971). Confirming this hypothesis, a great deal of previous scientific work reported that oyster shell meal (OSM) supplementation to the layer hen diet significantly improved egg breaking strength (Hauser \& Norris, 1946; Watkins et al., 1977; Keshevarz \& McCormick, 1991) and egg specific gravity (Makled \& Charles, 1987; Grizzle et al., 1992) when compared to limestone.

Meat and bone meal (MBM) is an excellent dietary source of protein, $\mathrm{Ca}$ and phosphorus (P) (Sell \& Jeffrey, 1996; Parsons et al., 1997; Shirley \& Parsons, 2001). Hence, using MBM as a feedstuff could contribute to the goal of providing limiting nutrients, $\mathrm{P}$ in particular. The economic value for MBM in poultry diets has been attributed equally between the mineral and protein content (Waldroup, 2002). The principal objective of MBM supplementation to poultry diets is to benefit from MBM's high protein, plentiful availability, and its cost effective P content (Dozier, 2000; Waldroup, 2002). However, MBM fortification of poultry diets also contributes to $\mathrm{Ca}$ content along with phosphorus since it contains considerable levels of Ca ranging from $6 \%$ to $12 \%$, depending on the bone ratio of the raw material (Wang \& Parsons, 1998a; Shirley \&Parsons, 2001). There have been few studies investigating the dietary administration to laying hens of MBM as a supplemental Ca source of animal origin, especially at older hen ages.

Indeed, considerably higher levels of dietary Ca levels (4\% or more) have been suggested by breeders of modern layer breeds during the older age phases in order to compensate for higher Ca requirements. In spite of this, limited reports are available, re-defining the availability of alternative dietary Ca sources to limestone. Therefore, in the present study, MBM and OSM, either alone or in combination, partly replaced limestone or dicalcium phosphate in order to evaluate the influences of these feeding regimens on performance and egg quality of laying hens during the entire second production phase.

\section{Material and Methods}

Four hundred and thirty-two 85-week old layer hens of a brown egg layer strain (Brown Nick), at the initiation of the second egg production period, were housed in cages located in a three-deck battery-type cage block. Birds were randomly assigned to four dietary treatments. Each treatment consisted of six replications of three cages and the hens of three adjacent cages were considered to be an experimental replicate (18 hens per replicate and 108 hens per treatment). The dimensions of each cage were, $60 \mathrm{~cm}$ long, $50 \mathrm{~cm}$ wide and 56 $\mathrm{cm}$ high, and six hens were placed in each cage. Hens were housed in an open-sided, naturally ventilated experimental hen house and the room temperature ranged from 19 to $30^{\circ} \mathrm{C}$ throughout the laying cycle. The experiment was carried out over a 21 week period, with the hens being between 85 and 105 weeks old, soon after the forced-moulting procedure. The Ministry of Agriculture, General Directorate of Research Institutional Animal Care and Use Committee approved the techniques and procedures involved in the animal care and handling (Protocol No: 2007-493).

To induce moult, the hens were starved using the conventional feed withdrawal method for 12 days without restricting drinking water. The hens lost $25 \%$ of their initial body weight during 81 and 82 weeks of age. Immediately after that, from the beginning of the $83^{\text {rd }}$ week of age, the hens were fed the experimental diets until the end of the experiment. All experimental data were recorded from the beginning of the $85^{\text {th }}$ week of age when the average egg production rate of the flock had reached $25 \%$, and was continued for 21 weeks of lay.

The ingredient and nutrient composition of the experimental diets are presented in Table 1. Three of the four experimental feeding regimens were based on alternative supplementary $\mathrm{Ca}$ sources to that of limestone. The Ca source treatments were limestone (LMS), LMS with meat and bone meal (MBM), LMS with oyster shell meal (OSM) and LMS with MBM + OSM combination, respectively. For the first treatment, the hens received a basal diet with only ground limestone as a control without MBM and OSM. 
MBM was supplemented at a $4 \%$ inclusion level, replacing dicalcium phosphate (DCP) in treatment two. Since MBM is also rich in both $\mathrm{P}$ and $\mathrm{Ca}$, it substituted dietary supplemental DCP according to a least-cost formulation programme. The hens in the third treatment received this diet with $2 \%$ OSM replacing $2.4 \%$ limestone in the basal diet $(0.25 \mathrm{OSM}+0.75 \mathrm{LMS})$. The hens in the fourth treatment were fed $4 \% \mathrm{MBM}+$ $2 \%$ OSM (combination approach).

Table 1 Ingredients and chemical composition of the experimental layer diets (as fed)

\begin{tabular}{|c|c|c|c|c|}
\hline Ingredients (g/kg) & LMS & MBM & OSM & MBM+OSM \\
\hline Maize & 303.2 & 328.1 & 305.4 & 330.3 \\
\hline Wheat & 330.0 & 330.0 & 330.0 & 330.0 \\
\hline Soybean meal (48\%) & 157.9 & 120.2 & 157.6 & 119.7 \\
\hline Full fat soybean & 33.0 & 33.0 & 33.0 & 33.0 \\
\hline Sunflower meal (29\%) & 40.0 & 40.0 & 40.0 & 40.0 \\
\hline Soybean oil & 24.9 & 13.5 & 24.2 & 12.8 \\
\hline Meat and bone meal & - & 40.0 & - & 40.0 \\
\hline Oyster shell meal & - & - & 20.0 & 20.0 \\
\hline Salt & 2.38 & 1.67 & 2.31 & 1.60 \\
\hline Ground limestone & 86.8 & 87.1 & 65.8 & 66.1 \\
\hline Dicalcium phosphate & 15.32 & - & 15.26 & - \\
\hline Vitamin premix ${ }^{1}$ & 2.50 & 2.50 & 2.50 & 2.50 \\
\hline Mineral premix ${ }^{2}$ & 1.00 & 1.00 & 1.00 & 1.00 \\
\hline DL-methionine & 1.03 & 1.06 & 1.03 & 1.06 \\
\hline Sodium bicarbonate & 0.50 & 0.50 & 0.50 & 0.50 \\
\hline Choline chloride & 0.50 & 0.50 & 0.50 & 0.50 \\
\hline Antioxidant $^{3}$ & 1.00 & 1.00 & 1.00 & 1.00 \\
\hline Total & 1000 & 1000 & 1000 & 1000 \\
\hline \multicolumn{5}{|l|}{ Chemical analysis ( $\mathrm{g} / \mathrm{kg}$ ) } \\
\hline Dry matter & 894 & 895 & 894 & 895 \\
\hline Crude protein & 164 & 163 & 167 & 166 \\
\hline Ether extract & 56.4 & 53.3 & 55.8 & 52.7 \\
\hline Crude fibre & 46.6 & 46.7 & 46.6 & 46.8 \\
\hline Crude ash & 131 & 130 & 129 & 128 \\
\hline Calcium & 37.9 & 3.8 .5 & 38.9 & 39.2 \\
\hline Total phosphorus & 6.7 & 6.5 & 6.8 & 6.4 \\
\hline Lysine $^{4}$ & 7.4 & 7.2 & 7.4 & 7.2 \\
\hline Methionine + cystine ${ }^{4}$ & 6.5 & 6.5 & 6.5 & 6.5 \\
\hline Arginine $^{4}$ & 10.2 & 10.2 & 10.2 & 10.2 \\
\hline Threonine $^{4}$ & 5.8 & 5.6 & 5.8 & 5.6 \\
\hline Metabolisable energy $(\mathrm{MJ} / \mathrm{kg})^{4}$ & 11.80 & 11.89 & 11.93 & 11.86 \\
\hline
\end{tabular}

LMS - Diet with added lime stone; MBM - Diet with added meat and bone meal at 4\%; OSM - Diet with added oyster shell meal at $2 \%$; MBM+OSM - Diet with added meat and bone meal at 4\% plus $2 \%$ OSM.

${ }^{1}$ Supplied per kilogram of diet: $12000 \mathrm{IU}$ vitamin A; $2400 \mathrm{IU}$ vitamin $\mathrm{D}_{3}$; $30 \mathrm{IU}$ vitamin E; $2.5 \mathrm{mg}$ vitamin $\mathrm{K}_{3} ; 3 \mathrm{mg}$ vitamin $\mathrm{B}_{1} ; 7 \mathrm{mg}$ vitamin $\mathrm{B}_{2} ; 20 \mathrm{mg}$ niacin; $8 \mathrm{mg}$ calcium D-pantothenate; $4 \mathrm{mg}$ vitamin $\mathrm{B}_{6} ; 0.015 \mathrm{mg}$ vitamin $\mathrm{B}_{12} ; 1$ $\mathrm{mg}$ folic acid; $0.045 \mathrm{mg}$ D-biotine; $50 \mathrm{mg}$ vitamin C.

${ }^{2}$ Supplied per kilogram of diet: $80 \mathrm{mg}$ manganese, $80 \mathrm{mg}$ iron, $60 \mathrm{mg}$ zinc, $5 \mathrm{mg}$ copper, $0.2 \mathrm{mg}$ cobalt, $0.5 \mathrm{mg}$ iodine, $0.15 \mathrm{mg}$ selenium.

${ }^{3}$ Supplied per kilogram of diet $15 \mathrm{mg}$ BHA, $80 \mathrm{mg}$ ethoxyquin, $180 \mathrm{mg}$ BHT, $60 \mathrm{mg}$ citric acid.

${ }^{4}$ Calculated values. 
The feed ingredients and experimental diets were analyzed for their dry matter, crude protein, ether extract, crude ash, crude fibre, $\mathrm{Ca}$ and total $\mathrm{P}$ concentrations according to the methods of the AOAC (1984). The metabolisable energy of feed ingredients was calculated based on the equation of Anonymous (1991).

The MBM was obtained from a rendering facility as animal meal processed from the slaughter of cattle. Analyzed dry matter, ash, ether extract, crude protein, crude fibre, total P, Ca content and total bacteria count derived from the used MBM sample were respectively $(\mathrm{g} / \mathrm{kg}): 986,362,192.3,401.9,20.3$, 80.8, 82.8 and $4 \times 10^{2}$. No mould, E. coli or Salmonella contamination was detected in the analyzed MBM, OSM and experimental diet samples (FDA, 2001). The limestone (Yatağan, Muğla, Turkey) contained $360 \mathrm{~g}$ $\mathrm{Ca} / \mathrm{kg}$ and was supplied as powder or in particles with a theoretical particle size of $1820 \mu \mathrm{m}$. The oyster shell meal, which was the ground by-product of endemic species of oyster (Venus gallina), was harvested from the Black sea coast (Sinop, Turkey), and contained $374 \mathrm{~g} \mathrm{Ca} / \mathrm{kg}$. It was supplied in particles with an expected mean particle size of $232 \mu \mathrm{m}$. Mean particle size of limestone and oyster shell were determined through sieving the samples using a Retsch shaker (Retsch, Stuttgart, Germany). The OSM samples were analyzed for lead, cadmium, arsenic and mercury contents to determine the level of heavy metal by using an ICP-OES (Perkin Elmer Optima 2100 DV). Analyzed lead $(2.49 \mathrm{mg} / \mathrm{kg})$, cadmium $(<0.4 \mathrm{mg} / \mathrm{kg})$, arsenic $(<1.0 \mathrm{mg} / \mathrm{kg})$ and mercury $(0.05 \mathrm{mg} / \mathrm{kg})$ levels were lower than detection limits. The MBM and OSM were preserved in airtight containers and stored at $10{ }^{\circ} \mathrm{C}$ in an air-conditioned room. Feed was prepared at weekly intervals.

All experimental diets met or exceeded the NRC (1994) nutrient recommendations for laying hens at older ages. Diets were formulated as isoenergetic and isonitrogenous and were also equal in $\mathrm{Ca}$ and $\mathrm{P}$ levels. Diets (in mash form) and water were provided for ad libitum consumption. A photoperiod of 16 hours/day was maintained for the duration of the laying phase.

All hens were weighed individually on weeks 81,85 and 105 of the experiment. The percentage rate of egg production was recorded daily from 85 to 105 weeks of age. During this period, a random sample of 30 eggs per treatment per day was collected on two consecutive days every week (five eggs per replicate per day). Hence, a total of 5040 eggs were weighed to determine the average egg weight throughout the trial. Feed intake was recorded on a weekly basis. Feed conversion ratio (FCR) was expressed as $\mathrm{kg}$ of feed consumed per kg of egg produced. Egg mass was calculated by multiplying egg weight by egg production. The magnitude of production variables such as feed intake and egg production were adjusted for hen mortalities. Deaths were recorded daily as they occurred.

External egg quality characteristics including egg shape index, eggshell weight, eggshell thickness, eggshell breaking strength, and internal egg quality characteristics including albumen height and Haugh unit (HU) were monitored at the end of every 28 day period. The external and internal egg quality characteristics were evaluated using a random sample of four eggs from each replicate, totalling 24 eggs from each treatment. When determining egg quality characteristics, the sample of eggs was individually weighed at initiation. Afterwards, the egg shape index was calculated by dividing egg length by egg width. Eggshell strength was measured using eggshell testing equipment (Egg Force Reader, SANOVO Technology A/S, Odense NV, Denmark) and expressed as a unit of compression force that was exposed to the unit eggshell surface area $\left(\mathrm{kg} / \mathrm{cm}^{2}\right)$. Then, the eggs were cracked carefully and the eggshell separated. Albumen height was obtained using a digital micrometer (model IT-014UT, Mitutoya, Kawasaki, Japan). Haugh unit was calculated using the formula described by Roush (1981). Eggshell weight was expressed as a percentage of the egg weight. After removing the shell membranes manually, eggshell thickness (without inner and outer shell membranes) was measured at three different points (top, middle, and bottom) using a micrometer. An average of three different thickness measurements of an egg was described as eggshell thickness.

Eighteen birds were randomly selected from each treatment group (three hens per replicate pen) at the end of the trial. Blood samples were collected by cardiac puncture and were placed into blood collection tubes without anticoagulant for separating the serum. Sera were separated by centrifugation at $3000 \mathrm{rpm}$ after 1 hour incubation at room temperature, and stored at $-20{ }^{\circ} \mathrm{C}$ until analysis. Serum $\mathrm{Ca}$, inorganic $\mathrm{P}(\mathrm{Pi})$ concentrations and alkaline phosphatase (ALP) activity were measured with a spectrophotometer (Hitachi, 911) using commercial kits (Roche, Basel, Sweden).

The experiment was a completely randomized design, and the experimental unit was the replicate consisting of six adjacently caged birds fed as one group. Data were analyzed as an one-way ANOVA using the GLM procedure of SAS software (1991). Duncan's multiple range test was carried out to detect the 
differences among treatments Significant differences between treatment means were separated using Duncan's multiple range test, with a $5 \%$ probability $(P<0.05)$.

\section{Results and Discussion}

Body weight at the beginning of the induced moult $\left(81^{\text {st }}\right.$ week of age), three weeks after feeding treatments were initiated $\left(85^{\text {th }}\right.$ week of age $)$, and at the end of the trial $\left(105^{\text {th }}\right.$ week of age $)$ are given in Table 2. The final body weight for hens fed on a diet with OSM was significantly higher than hens fed MBM and all-limestone diets, and was also higher than for hens fed MBM+OSM. Neither MBM nor OSM supplementation to the diet as Ca supplements of animal origin affected hen mortality (Table 2).

Table 2 Body weight and mortality of hens given diets added with LMS, MBM, OSM and MBM+OSM

\begin{tabular}{lcccc}
\hline Supplemental calcium source & \multicolumn{3}{c}{ Body weight (g) } & $\begin{array}{c}\text { Mortality } \\
(\%)\end{array}$ \\
\cline { 2 - 3 } & 81 st wk & 85 th wk & 105 th wk & $2120^{\mathrm{b}}$ \\
LMS & 2059 & $2102^{\mathrm{a}}$ & $2115^{\mathrm{b}}$ & 6.18 \\
MBM & 2051 & $2022^{\mathrm{b}}$ & $2201^{\mathrm{a}}$ & 5.42 \\
OSM & 2083 & $2090^{\mathrm{a}}$ & $2158^{\mathrm{ab}}$ & 5.76 \\
MBM + OSM & 2080 & $2059^{\mathrm{ab}}$ & 22.73 & 3.75 \\
SEM & 18.89 & 20.35 & 0.0270 & 1.63 \\
Probability & 0.5478 & 0.0283 & 0.6860
\end{tabular}

LMS - Diet with added lime stone; MBM - Diet with added meat and bone meal at 4\%; OSM - Diet with added oyster shell meal at 2\%; MBM+OSM - Diet with added meat and bone meal at $4 \%$ plus $2 \%$ OSM.

a,b Column means with common superscripts differ significantly at $P<0.05$.

Egg production rate, egg weight, egg mass, feed intake, FCR of laying hens fed on diets with different complementary $\mathrm{Ca}$ regimens are presented in Table 3. The origin of the supplemental $\mathrm{Ca}$ sources significantly affected all performance traits examined except for the FCR $(P<0.05)$. The egg production rate in hens given OSM added to the diet was higher than all other treatments $(P<0.01)$. There were also significant differences among LMS, MBM and MBM+OSM treatments in terms of egg production rate. MBM supplementation to the layer hen diet led to a reduction of $1.14 \%$ in the egg production rate compared to the control treatment. However, the combined supplementation MBM with OSM resulted in a better production rate than that of the control treatment. These results are in conflict with some earlier reports indicating that MBM supplementation to a layer hen diet provided either slight improvements (Bozkurt et al.,

Table 3 The effect of different supplemental calcium regimens on productive performance of layer hens

\begin{tabular}{lccccc}
\hline $\begin{array}{l}\text { Supplemental } \\
\text { Ca source }\end{array}$ & $\begin{array}{c}\text { Egg production } \\
\text { rate }(\%)\end{array}$ & $\begin{array}{c}\text { Egg weight } \\
(\mathrm{g})\end{array}$ & $\begin{array}{c}\text { Egg mass } \\
(\mathrm{g})\end{array}$ & $\begin{array}{c}\text { Feed intake } \\
(\mathrm{g})\end{array}$ & $\begin{array}{c}\text { Feed conversion } \\
\text { ratio }(\mathrm{g} \text { feed/g egg) }\end{array}$ \\
\hline LMS & $72.61^{\mathrm{c}}$ & $68.18^{\mathrm{a}}$ & $49.52^{\mathrm{b}}$ & $108.97^{\mathrm{b}}$ & 2.204 \\
MBM & $71.47^{\mathrm{d}}$ & $68.39^{\mathrm{a}}$ & $48.87^{\mathrm{b}}$ & $110.21^{\mathrm{b}}$ & 2.268 \\
OSM & $75.13^{\mathrm{a}}$ & $68.26^{\mathrm{a}}$ & $51.29^{\mathrm{a}}$ & $112.83^{\mathrm{a}}$ & 2.209 \\
MBM + OSM & $73.85^{\mathrm{b}}$ & $67.40^{\mathrm{b}}$ & $49.75^{\mathrm{b}}$ & $110.66^{\mathrm{ab}}$ & 2.226 \\
SEM & 0.40 & 0.12 & 0.50 & 0.86 & 0.03 \\
$P$ & 0.0001 & 0.0001 & 0.0094 & 0.0169 & 0.6272
\end{tabular}

LMS - Diet with added lime stone; MBM - Diet with added meat and bone meal at 4\%; OSM - Diet with added oyster shell meal at 2\%; MBM+OSM - Diet with added meat and bone meal at $4 \%$ plus $2 \%$ OSM.

a,b,c,d Column means with common superscripts differ significantly at $P<0.05$. 
2004) or no benefit (Giuliotti \& Cucco, 1994; Oruseibio, 1995) in egg production. Inconsistent results between the present and previous works could be due to the notable differences in nutrient composition of MBM batches used; there are sometimes differences in protein, fat, amino acid, ash, $\mathrm{Ca}$ and $\mathrm{P}$ compositions.

In fact, some preliminary works pointed out that the raw material source, processing systems, processing temperature and especially the processing pressure can reduce the amino acid digestibility of MBM (Wang \& Parsons, 1998a; b; Shirley \& Parsons, 2001). Wang et al. (1997) emphasized that the digestibility of the first limiting amino acids varied considerably when 37 MBM samples were analysed. Hence, Wang \& Parsons (1998b) advised that the formulation of diets should be done on the basis of the digestibility of the amino acids rather than on total amino acids concentration when MBM was supplemented to diets. We formulated diets to be isonitrogenous and equal in essential amino acid levels. However, the digestibility of several essential amino acids in MBM used in this experiment might have been lower than we assumed. Therefore, the reason for the lower egg production rate $(1.14 \%)$ in the MBM fed hens could be due to a reduced amino acid digestibility in the MBM that might be associated with the processing procedure of the raw material.

The significant improvement in egg production with dietary OSM supplementation in our study was confirmed by earlier studies extending to the late 1940s (Hauser \& Norris, 1946; Scott et al., 1971; De Faria et al., 2000). These authors indicated that hens receiving the diet with oyster shells produced more eggs on less feed than were obtained with the all-limestone diet. The combination of MBM with OSM did not produce any further improvements either in egg production rate or other performance traits examined, whilst it induced a significant reduction in egg weight. This was not the case when either MBM or OSM was included in the diets. The mechanism by which this was brought about is not clear. In agreement with our findings, some other authors reported that the egg weight of layer hens was not affected by dietary OSM supplementation (Proudfoot \& Hulan, 1987; Guinotte \& Nys, 1991; Keshevarz \& McCormick, 1991; Safaa et al., 2008). However, our findings are in contrast with a previous work (Bozkurt et al., 2004) indicating notable depression in egg weight when hens were given MBM. The negative correlation between ash content and digestibility of many essential amino acids in MBM samples was found responsible for the depressed egg weight (Ravindran et al., 2002).

In accordance with the higher egg production rate, hens fed with OSM supplemented diets produced a considerably higher egg mass than all of the other groups $(P<0.01)$. Treatments of LMS, MBM and $\mathrm{MBM}+\mathrm{OSM}$, however, were not different from one another $(P>0.01)$. The higher daily feed intake $(3.86 \mathrm{~g})$ in hens given an OSM supplemented diet as compared to that of control hens increased the egg production rate, and consequently the egg mass output. In contrast with our present findings, some other studies indicated that dietary OSM supplementation did not influence the daily feed consumption of layer hens; even when OSM totally replaced limestone (Scott et al., 1971; Cheng \& Coon, 1990; De Faria et al., 2000; Safaa et al., 2008). One possible explanation for the discrepancies in feed intake between our trial and other studies could be the differences in ingredient composition of experimental diets, inclusion rate and size of the oyster shell particles used. It is noteworthy that the dietary inclusion rate in the present study was lower (23\%). The larger particle size of oyster shells might attract the hens particularly during the afternoon when hens were unwilling to consume feed due to the high environmental temperatures in the hen house through the summer season. In contrast to OSM, MBM supplementation had little effect on feed intake. In agreement with our findings, no palatability problem was reported in layer hens fed on diets with added MBM (Giuliotti \& Cucco, 1994; Oruseibio, 1995; Bozkurt et al., 2004). Unfortunately, we were not able to attain any scientific information on whether the OSM or MBM gives a certain taste/flavour to diets that layer hens find attractive.

In contrast to the performance traits presented above, the FCR was not affected by the origin of supplementary $\mathrm{Ca}$ sources. Some previous scientific publications also confirmed that laying hens did not benefit from either MBM (Oruseibio, 1995; Bozkurt et al., 2004) or OSM (Brister et al., 1981; Makled \& Charles, 1987; Grizzle et al., 1992; De Faria et al., 2000; Safaa et al., 2008) supplementation of the diet.

The effects of the origin of dietary Ca source on selected egg quality characteristics are shown in Table 4. The origin of supplemental dietary Ca source significantly affected eggshell thickness, eggshell breakage strength, albumen height and Haugh unit, whereas egg shape index and eggshell weight were not influenced $(P>0.05)$. MBM supplementation increased EST and ESS compared to all other treatments $(P$ $<0.05$ ). Supplementing the layer hen diet with MBM provided slightly more benefits on ALH and HU, as essential indicators of internal egg quality, over the LMS and OSM treatments. Combining MBM with OSM provided no benefit in terms of ALH and HU. 
Table 4 The effects of origin of dietary Ca sources on some egg quality parameters

\begin{tabular}{lcccccc}
\hline $\begin{array}{l}\text { Supplemental } \\
\text { Ca source }\end{array}$ & ESI & ESW $(\%)$ & EST $(\mu)$ & ESS $\left(\mathrm{kg} / \mathrm{cm}^{2}\right)$ & ALH $(\mathrm{mm})$ & HU \\
\hline LMS & 77.30 & 10.99 & $345^{\mathrm{b}}$ & $1.754^{\mathrm{c}}$ & $5.90^{\mathrm{abc}}$ & $71.50^{\mathrm{bc}}$ \\
MBM & 77.42 & 11.03 & $353^{\mathrm{a}}$ & $2.008^{\mathrm{a}}$ & $6.01^{\mathrm{ab}}$ & $72.47^{\mathrm{ab}}$ \\
OSM & 76.54 & 11.19 & $346^{\mathrm{b}}$ & $1.847^{\mathrm{bc}}$ & $5.83^{\mathrm{bc}}$ & $71.24^{\mathrm{bc}}$ \\
MBM + OSM & 76.65 & 11.20 & $347^{\mathrm{b}}$ & $1.919^{\mathrm{ab}}$ & $5.65^{\mathrm{c}}$ & $70.22^{\mathrm{c}}$ \\
SEM & 0.16 & 0.07 & 1.90 & 0.05 & 0.07 & 0.66 \\
Probability & 0.3660 & 0.0563 & 0.0086 & 0.0092 & 0.0060 & 0.0078
\end{tabular}

ESI - egg shape index; ESW - eggshell weight; EST - eggshell thickness; ESS - eggshell breaking strength; ALH albumen height; $\mathrm{HU}$ - Haugh unit.

LMS - Diet with added lime stone; MBM - Diet with added meat and bone meal at 4\%; OSM - Diet with added oyster shell meal at 2\%; MBM+OSM - Diet with added meat and bone meal at $4 \%$ plus $2 \%$ OSM.

a,b,c,d Column means with common superscripts differ significantly at $P<0.05$.

Table 5 Serum Ca and Pi concentrations, and ALP activity in hens fed different dietary supplemental Ca regimens

\begin{tabular}{lccc}
\hline Supplemental Ca source & $\mathrm{Ca}(\mathrm{mg} / \mathrm{dL})$ & $\mathrm{Pi}(\mathrm{mg} / \mathrm{dL})$ & ALP $(\mathrm{IU} / \mathrm{L})$ \\
\hline LMS & $29.78^{\mathrm{ab}}$ & $6.93^{\mathrm{b}}$ & 516.41 \\
MBM & $29.50^{\mathrm{ab}}$ & $6.36^{\mathrm{b}}$ & 544.88 \\
OSM & $32.13^{\mathrm{a}}$ & $8.40^{\mathrm{a}}$ & 544.61 \\
MBM + OSM & $26.30^{\mathrm{c}}$ & $7.02^{\mathrm{b}}$ & 490.00 \\
SEM & 0.69 & 0.24 & 52.37 \\
Probability & 0.1140 & 0.0424 & 0.6494
\end{tabular}

Ca - calcium; Pi - inorganic phosphorus; ALP - alkaline phosphatase.

LMS - Diet with added lime stone; MBM - Diet with added meat and bone meal at 4\%; OSM - Diet with added oyster shell meal at 2\%; MBM+OSM - Diet with added meat and bone meal at $4 \%$ plus $2 \%$ OSM.

a,b,c Column means with common superscripts differ significantly at $P<0.05$.

The findings related to eggshell quality parameters examined in the present study indicated that MBM alone exerted notable contributions to those indices, with OSM not significantly different from LMS. In contrast to our findings, former studies concerning OSM supplementation showed beneficial effects on eggshell breakage strength (Watkins et al., 1977; Brister et al., 1981; Makled \& Charles, 1987; Proudfoot \& Hulan, 1987; Guinotte \& Nys, 1991; Grizzle et al., 1992; Ahmad \& Balander, 2004). The results of the present study further support some recent investigations by Lichovnikova (2007) and Safaa et al. (2008) who observed that oyster shell is less soluble than fine or coarse limestone, contradicting conventional theories of higher digestibility and retention associated with oyster shell by some researchers (Scott et al., 1971; Roland, 1988).

As for the results of this study, it appears that, when the supplemental Ca was supplied partly as MBM, OSM or in a combination of MBM + OSM, it was possible to maintain eggshell quality comparable to that achieved with ground limestone conventionally used as a supplemental $\mathrm{Ca}$ source in layer hen diets. This means partly replacing limestone with sources of animal origin might ensure eggs that have a good shell quality in older hens.

It is interesting to note that MBM, which is an excellent dietary source of $\mathrm{Ca}$ and $\mathrm{P}$, contributed more to eggshell formation and internal egg quality than OSM alone. Although all experimental diets were precisely balanced for dietary $\mathrm{P}$ and Ca content, dietary MBM supplementation resulted in stronger eggs with thicker shells as compared to those eggs obtained from hens fed on OSM. However, combining MBM 
with OSM did not produce any additive benefits on either eggshell quality or internal egg quality as compared with their individual uses.

Supplementation with OSM alone led to significant increases in serum $\mathrm{Ca}$ and $\mathrm{P}$ levels, whereas no significant differences were found among other treatments $(P>0.05)$. The results presented in Table 5 showed that the hens receiving 25\% oyster shell and 75\% limestone had higher blood $\mathrm{Ca}$ and $\mathrm{Pi}$ concentrations than those fed the LMS, MBM and MBM+OSM diets. The higher egg production in hens receiving the OSM supplemented diet in relation to the control $(51.3 \mathrm{~g} \mathrm{vs.} 49.5 \mathrm{~g}$ ) requires relatively more $\mathrm{Ca}$ and $\mathrm{P}$ circulation in the blood in order to maintain quality. Increased serum mineral concentration in association with extra daily feed intake appears to contribute to shell formation in OSM fed hens. Consistent with our results, Scott et al. (1971) reported that substitution of OSM for $2 / 3$ of limestone led to an improvement in serum Ca level of 17\%, whilst some others (Cheng \& Coon, 1990; Guinotte \& Nys, 1991) found no differences in plasma Ca levels when oyster shell was added to or replaced limestone. Serum ALP levels were not different among the treatments (Table 5).

\section{Conclusion}

The substitution of OSM for $25 \%$ of the limestone usually present in laying hen rations in ground form provided improvements in egg production rate and egg output with associated higher feed intake. Due to the fact that the use of OSM is often very limited because of its restricted supply, the results presented herein stress the significance of particle size of supplemental $\mathrm{Ca}$ sources in layer hen diets. The current data demonstrate that diets containing 4\% MBM supported egg quality at older hen ages. The results presented also have considerable economic implications. Since dietary MBM completely replaced dicalcium phosphate and supplemental fat, the need for two ingredients that are relatively costly and more importantly, rapidly becoming scarce, is decreased.

\section{References}

Ahmad, H.A. \& Balander, R.J., 2004. Physiological response of layers to alternative feeding regimen of calcium source and phosphorus level. Int. J. Poult. Sci. 3 (2), 100-111.

Anonymous, 1991. Animal feeds determination of metabolisable energy (chemical method). Turkish Standards Institute (TSE), Publ. No. 9610, pp. 1-3.

AOAC, 1984. Official Methods of Analysis (14th ed.), Association of Official Analytical Chemists, Inc., Arlington, Virginia, USA.

Bozkurt, M., Alçiçek, A. \& Çabuk, M., 2004. The effect of dietary inclusion of meat and bone meal on the performance of laying hens at old age. S. Afr. J. Anim. Sci. 34, 31-36.

Brister, R.D., Linton Jr, S.S., \& Creger, C.R., 1981. Effects of dietary calcium sources and particle sizes on laying hens performance. Poult. Sci. 60, 2643-2654.

Cheng, T.K. \& Coon, C.N., 1990. Effect on layer performance and shell quality of switching limestone with different solubilities. Poult. Sci. 69, 2199-2203.

De Faria, D.E., Junqueria, O.M., Sakomura, N.K. \& Santana, A.E., 2000. Feeding systems and oyster shell meal supplementation on the performance and egg shell quality of laying hens. Rev. Braz. Zootec. 29 (5), 1394-1401.

De Witt, F.H., Kuleile, N.P., Van der Merwe, H.J. \& Fair, M.D., 2008. Influence of limestone particle size on egg production and eggshell quality of layers. Wrld's Poult. Sci. J. 64 (Suppl. 2), 411.

Dozier, W.A., 2000. How to manage dietary phosphorous in environmentally sensitive areas. Feed Management 51, 10.

FDA, 2001. Bacteriological Analytical Manual. Food and Drug Administration (8th Rev. ed.) AOAC International, Gaithersburg, M.D., USA.

Giuliotti, L. \& Cucco, E., 1994. Administration of vegetable diets or diets with animal proteins and fats to laying hens. 1. Productive Traits. Rivista-di-Avicoltura 63 (9), 29-32.

Grizzle, J., Iheanacho, M., Saxton, A. \& Broaden, J., 1992. Nutritional and environmental factors involved in egg shell quality of laying hens. Br. Poult. Sci. 33, 781-94.

Guinotte, F. \& Nys, Y., 1991. Effect of particle size and origin of calcium sources on eggshell quality and bone mineralization in egg laying hens. Poult. Sci. 70, 583-592.

Hauser, G.F. \& Norris, L.C., 1946. Oyster shells, calcite grit, ground limestone, and granite grit in rations for hens. Poult. Sci. 25, 173-179. 
Hunton, P., 1995. Understanding the architecture of the eggshell. Wrld Poult. Sci. J. 51, 140-147.

Hunton, P., 2005. Research on egg shell structure and quality: An historical overview. Braz. J. Poult. Sci. Apr- June, 67-71.

Keshevarz, K. \& McCormick, C.C., 1991. Effect of sodium aluminosilicate, oyster shell and their combinations on acid- base balance and eggshell quality. Poult. Sci. 70, 313-325.

Keshevarz, K. \& Nakajima, S., 1993. Re-evaluation of calcium and phosphorus requirements of laying hens for optimum performance and eggshell quality. Poult. Sci. 72, 144-153.

Lichovnikova, M., 2007. The effect of dietary calcium source, concentration, and particle size on calcium retention, egg shell quality, and overall calcium requirement in laying hens. Br. Poult. Sci. 48, 71-75.

Makled, M.N. \& Charles, O.W., 1987. Eggshell quality as influenced by sodium bicarbonate, calcium source, and photoperiod. Poult. Sci. 66, 705-712.

Mongin, P. \& Sauveur, B., 1974. Voluntary food and calcium intake by laying hens. Br. Poult. Sci. 15, 349-359.

NRC, 1994. Nutrient Requirements of Poultry. (9th rev.) National Research Council. National Academy Press, Washington, D.C., USA.

Oruseibio, S.M., 1995. Comparison of straight protein diets with mixed protein diets on egg production. Discovery and Innovation 7, 151-162.

Parsons, A.H. \& Combs, G.F., 1981. Blood ionized calcium in the chicken. Poult. Sci. 53, 1520-1524.

Parsons, C.M., Castanon, F. \& Han, Y., 1997. Protein and amino acid quality of meat and bone meal. Poult. Sci. 76, 361-368.

Proudfoot, F.G. \& Hulan, H.W., 1987. Effect on shell strength of feeding supplemental sources of calcium to adult laying hens given insoluble grit during the rearing period. Br. Poult. Sci. 28, 381-386.

Rao, K.S. \& Roland Sr., D.A., 1989. Influence of dietary Ca level and particle size of Ca-source on in vivo Ca-solubilization by commercial leghorns. Poult. Sci. 68, 1499-1505.

Ravindran, V., Hendriks, W.H., Camden, B.J., Thomas, D.V., Morel, P.C.H. \& Butts, C.A., 2002. Amino acids digestibility of meat and bone meals for broiler chickens. Aust. J. Agric. Res. 53, 1257-1264.

Roberts, J., 2004. Factors affecting egg internal quality and egg shell quality in laying hens. J. Poult. Sci. 41, 161-177.

Roland Sr, D.A., 1988. Eggshell problems: Estimates of incidence and economic impact. Poult. Sci. 67, 1801-1803.

Roush, W.B.T., 1981. 159 calculator program for Haugh unit calculation. Poult. Sci. 60, 1086-1088.

Safaa, H.M., Serrano, M.P., Valencia, D.G., Frikha, M., Jiménez-Moreno, E. \& Mateos, G.G., 2008. Productive performance and egg quality of brown egg-laying hens in the late phase of production as influenced by level and source of calcium in the diet. Poult. Sci. 87, 2043-2051.

SAS, 1991. SAS ${ }^{\circledR}$ User's Guide: Statistics. Version 6.03 ed. SAS Institute Inc., Cary, N.C., USA.

Scott, M.L., Hull, S.J. \& Mullenhoff, P.A., 1971. The calcium requirements of laying hens and effects of dietary oyster shell upon egg shell quality. Poult. Sci. 50, 1055-1063.

Sell, J.L. \& Jeffrey, M.J., 1996. Availability for poults of phosphorus from meat and bone meals of different particle sizes. Poult. Sci. 75, 232-239.

Shirley, R.B. \& Parsons, C.M., 2001. Effect of ash content on protein quality of meat and bone meal. Poult. Sci. 80, 626-632.

Waldroup, P., 2002. The future of poultry nutrition. Poult. Int. 41 (7), 12-19.

Wang, X. \& Parsons, C.M., 1998a. Effect of raw material source, processing system, and processing temperatures on amino acid digestibility of meat and bone meals. Poult. Sci. 77, 834-841.

Wang, X. \& Parsons, C.M., 1998b. Bioavailability of the digestible lysine and total sulfur amino acids in meat and bone meals varying in protein quality. Poult. Sci. 77, 1003-1009.

Wang, X., Castanon, F. \& Parsons, C.M., 1997. Order of amino acid limitation in meat and bone meal. Poult. Sci. 76, 54-58.

Watkins, R.M., Dilworth, B.C. \& Day, E.J., 1977. Effect of calcium supplement particle size and source on the performance of laying chickens. Poult. Sci. 56, 1641-1647. 